\title{
Populasi Bakteri dan Jamur pada Daging Sapi dengan Penyimpanan Suhu Rendah
}

\author{
A. H. T. Prihharsanti \\ Jurusan Peternakan, Fakultas Pertanian, Universitas Mercu Buana, Yogyakarta
}

\begin{abstract}
ABSTRAK
Daging sapi merupakan tempat yang ideal untuk kehidupan bakteri dan jamur dan merupakan bahan pangan yang penting. Penyimpanan daging pada suhu rendah dapat menghambat pertumbuhan bakteri dan jamur. Tujuan penelitian ini adalah untuk mengetahui pengaruh suhu penyimpanan terhadap populasi bakteri dan jamur. Bahan yang digunakan adalah daging sapi. Daging disimpan pada suhu penyimpanan $28-30^{\circ} \mathrm{C}$ (suhu kamar) $9-12^{\circ} \mathrm{C}$ (suhu dalam refrigerator) dan $0-1^{\circ} \mathrm{C}$ (suhu dalam freezer). Lama penyimpanan adalah 0;3;6;9;12;15 dan 18 jam. Untuk medium buatan digunakan kaldu nutrisi sebagai medium pertumbuhan bakteri dan agar kentang dekstrosa untuk jamur. Peubah yang diamati adalah jumlah koloni bakteri dan jumlah koloni jamur. Untuk mengetahui awal pembusukan diuji dengan uji Eber. Rancangan percobaan yang digunakan adalah Rancangan Acak Lengkap pola faktorial 3x7 dengan 3 ulangan. Data diuji dengan analisisi variansi, dilanjutkan dengan uji Ducan. Hasil penelitian menunjukkan bahwa lama penyimpanan dan suhu berpengaruh nyata $(\mathrm{P}<0,05)$ terhadap jumlah bakteri maupun jamur. Pada penyimpanan dalam freezer jumlah koloni bakteri maupun jamur sangat sedikit.
\end{abstract}

Kata kunci: Daging, bakteri , jamur, suhu

The bacteria and mold population in the meat at the cold storage temperature

\begin{abstract}
Meat is an important food but is also an ideal place for microorganism to life. Some of them might cause damage in food materials. Low storage temperature will slow down the growth of microorganisms. The purpose of the study was to know the influence of storage temperature on bacteria and mold population. Meef meat was stored at $28-30^{\circ} \mathrm{C}($ room temperature $), 9-12^{\circ} \mathrm{C}$ (refrigerator temperature) and $0-1^{\circ} \mathrm{C}($ freezer temperature). Length of storage time were 0;3;6;9;12;15; and 18 hours. Medium, nutrition broth was used as medium for bacterial growth and potato dextrose jelly for the mold. Variables observed were number of bacteria colonies and mold. To know the beginning of deteriotation, Eber test was done.The experimental design was Completely Ramdomized Design factorial $3 \times 7$ with 3 replications. The collected data were statistically analyzed by using variance analysis and Ducan Multiple Range Test. The storage length and the storage temperature affected $(P<0,05)$ bacteria and mold population in the freezer. The low storage temperature in freezer resulted a smaller microorganism population in the meat.
\end{abstract}

Key words: Meat, bacteria, mold, storage 


\section{PENDAHULUAN}

Sapi merupakan hewan ternak yang produk utamanya adalah daging atau susu. Ketersediaan daging sapi perlu didukung oleh teknik penyimpanan yang tepat. Daging sapi merupakan produk yang digemari oleh masyarakat, dan merupakan sumber protein hewani yang sangat baik. Sebagai bahan makanan yang mempunyai nilai gizi tinggi, daging sapi merupakan media yang subur bagi pertumbuhan bakteri dan jamur, sehingga penanganan daging harus mendapatkan perhatian yang benar. Komposisi kimia dan kelembaban daging sangat ideal untuk berlangsungnya proses kehidupan bakteri dan jamur. Hal ini menyebabkan daging tidak dapat bertahan lama bila disimpan pada suhu kamar. Mikroorganisma kontaminan yang banyak hidup pada daging sapi adalah bakteri dan jamur. Kedua mikroorganisme tersebut sangat potensial merusak. Daging mengandung sekitar 75\% air, atau berkisar antara 65-85\%. Air merupakan konstituen utama cairan ekstra seluler. Di dalam air banyak senyawa kimia yang terlarut maupun yang tersuspensi. Air merupakan medium transportasi diantara serat daging sehingga kadar air berperan peting pada kehidupan mikroorganisme (Soeparno, 1994). Proses pendinginan dapat mengurangi kadar air pada daging. Lemak pada daging adalah lemak-lemak netral dan fosfolipid yang pada kondisi cair sangat disukai oleh mikroorganisme. Dengan pendinginan, lemak akan menjadi padat. Protein pada jaringan hewan dibedakan menjadi 3 (tiga) fraksi berdasarkan kelarutannya (Soeparno, 1994). Sarpkoplasma adalah protein yang larut pada air, miofibril larut pada saline, dan stroma adalah protein jaringan ikat yang tidak larut pada air maupun saline. Protein digunakan oleh mikroorganisme melalui proses metabolisme yang enzimatis. Proses metabolisme adalah serangkain reaksi kimia sel. Sebagai rangkaian proses kimia maka metabolisme akan terhambat pada kondisi suhu rendah. Kandungan karbohidrat pada daging memang sangat rendah, terutama dalam bentuk glikogen yaitu berkisar 0,5-13\%. Selain itu daging juga mengandung bahan-bahan anorganik yang berperan sebagai kation dan anion (Naruki dan Kanoni, 1992). Kation dan anion sangat membantu proses metabolisme pada setiap organisme.

Ketersediaan nutrisi yang lengkap pada daging merupakan tempat yang ideal bagi kehidupan bakteri dan jamur. Seperti halnya mikroorganisma pada umunya, fase pertumbuhan bakteri dan jamur secara berturutturut adalah sebagai berikut: Fase adaptasi, fase pertumbuhan awal, fase pertumbuhan logaritmik, fase pertumbuhan lambat, fase statis dan fase kematian (Fardias, 1989). Pada fase adaptasi mikroorganisme belum melakukan kegiatan enzimatis pada media, sehingga kondisi daging belum banyak mengalami perubahan. Memperpanjang waktu adaptasi ini berarti menunda terjadinya perubahanperubahan pada daging.

Pertumbuhan bakteri dan jamur selalu diikuti dengan kegiatan enzimatis, sehingga akan merubah komposisi kimia media. Perubahan komposisi tersebut terekspresi dalam bentuk pembusukan, sehingga tidak layak lagi untuk dikonsumsi (Tranggono et al. 1990). Kerusakan dapat dipercepat oleh kenaikan suhu, kelembaban dan ketersediaan oksigen (Soeparno, 1994). Dalam hal ini faktor yang paling mudah dikendalikan adalah suhu. Untuk memelihara daging dalam waktu yang agak panjang, di lingkungan rumah tangga atau pedagang pengecer biasanya menggunakan pengawetan dengan sistem pendinginan karena paling praktis dan aman. Suhu dingin dapat menghambat kerusakan daging karena dalam waktu tertentu aktivitas bakteri dan jamur masih ditujukan untuk beradaptasi (Bernholdt, 1975). Bila adaptasi telah tercapai, maka aktivitas akan terjadi dan segera akan disertai dengan peningkatan jumlah bakteri dan jamur, sehingga lama penyimpanan perlu dibatasi. Batasan lama penyimpanan, berbeda untuk 
suhu yang berbeda. Berbagai cara dalam penanganan daging yang masih segar, pada prinsipnya adalah dengan menekan aktivitas bakteri dan jamur (Soeparno, 1994). Keberhasilan dalam menekan aktivitas bakteri dan jamur tercermin pada jumlah bakteri dan jamurnya. Jumlah bakteri dan jamur yang lebih sedikit berarti aktivitasnyapun lebih sedikit sehingga proses enzimatisnya juga terbatas. Proses enzimatis mempercepat degradasi senyawa-senyawa penyusun .

Laju pertumbuhan bakteri dan jamur sangat ditentukan oleh suhu lingkungan. Pada umumnya, bakteri dan jamur tersebut tumbuh optimal pada suhu $10^{\circ}-40^{\circ}$ Celcius. Informasi tentang jumlah bakteri dan jamur yang tumbuh pada penyimpanan dengan suhu yang berbeda belum banyak, atau bahkan belum ada. Secara umum dalam kehidupan sehari-hari dikenal 3(tiga) lingkungan suhu penyimpanan. Lingkungan tersebut adalah suhu kamar (20$\left.35^{\circ} \mathrm{C}\right)$, Refrigerator $\left(5-7^{0} \mathrm{C}\right)$ dan freezer (0 sd $5^{0} \mathrm{C}$ ). Sehubungan dengan itu maka telah dilakukan penelitian tentang pengaruh penyimpanan pada suhu yang berbeda yaitu pada suhu kamar, Refrigerator dan freezer terhadap jumlah bakteri dan jamur. Untuk melengkapi informasi tentang kesegaran daging yang disimpan dilaporkan juga hasil pengujian awal pembusukan menggunakan larutan Eber.

Penelitian ini diharapkan bermanfaat bagi para pedagang pengecer dan konsumen daging untuk menentukan suhu penyimpanan yang sesuai dengan waktu penggunaannya. Bagi masyarakat ilmiah, penelitian ini dapat digunakan sebagai perbandingan untuk melakukan penelitian lebih lanjut tentang teknologi pengendalian pertumbuhan mikroorganisme pada daging sapi.

\section{MATERI DAN METODE}

Daging sapi peranakan Ongole bagian lulur (Longisidimus dorsi). Medium padat selektif Agar Kaldu Nutrisi (AKN) untuk media kultur bakteri Agar Kentang Dekstrosa (AKD) untuk media kultur jamur Reagen Eber untuk uji pembusukan.

Rancangan Percobaan yang digunakan adalah Rancangan Acak Lengkap Pola Faktori 3 X 7 X 3 yaitu dengan 3 suhu penyimpanan (suhu kamar, Refrigerator \& Freezer),7 macam waktu penyimpanan $(0 ; 3 ; 6 ; 9 ; 12 ; 15$ \& 18 jam) dan 3 Ulangan.

Penghitungan koloni bakteri dan jamur dilakukan dengan cara tidak langsung yaitu dengan menghitung jumlah koloni yang tumbuh pada media buatan, dengan asumsi bahwa koloni berasal dari satu spora. Proses penanaman mikroorganisma daging pada media buatan adalah sebagai berikut: AKN dan AKD disiapkan sebagai media buatan, pada cawan petri dalam kondisi beku. Selanjutnya, 1 gram sampel daging perlakuan disuspensikan dengan pengenceran $10^{4} \mathrm{X}$ menggunakan aquades. Dari hasil suspensi daging, $1 \mathrm{ml}$ suspensi ditabur pada AKN dan $1 \mathrm{ml}$ suspensi ditabur pada AKD. Pada keadaan cawan petri tebalik, biakan diinkubasikan dan koloni bakteri dan jamur dihitung setelah 24 jam.

Uji Pembusukan Daging ukuran $(0,50 \times 0,50 \times 0,50) \mathrm{Cm}^{3}$ dimasukkan dalam tabung reaksi kemudian dituangi $5 \mathrm{ml}$ reagen Eber. Tabung ditutup rapat jika tidak terbentuk embun putih berarti daging belum busuk dan jika terbentuk embun putih $\mathrm{NH}_{4} \mathrm{Cl}$ berarti daging telah busuk.

Data kuantitatif yang terkumpul dianalisis dengan Analisis Variansi (Anova). Dari hasil Anova yang menunjukkan ada perbedaan maka dilanjutkan dengan Duncan's Multiple Range Test untuk mengetahui letak pengaruh perlakuan yang berbeda.

\section{HASIL DAN PEMBAHASAN}

\section{Populasi Bakteri Pada Daging}

Rata-rata jumlah bakteri pada penyimpanan daging di suhu kamar, refrigerator dan freezer dalam waktu yang 
Tabel 1. Jumlah Bakteri pada daging dengan suhu dan lama penyimpanan yang berbeda $\left(10^{4}\right.$ /gram $)$

\begin{tabular}{ccccc}
\hline \hline \multirow{2}{*}{$\begin{array}{c}\text { Lama (jam) } \\
\text { penyimpanan }\end{array}$} & \multicolumn{3}{c}{ Suhu Penyimpanan } & \multirow{2}{*}{ Rata-rata } \\
\cline { 2 - 4 } & Kamar & Refrigerator & Freezer & 40,00 \\
3 & $40,00^{\mathrm{c}}$ & $0,30^{\mathrm{c}}$ & $49,67^{\mathrm{c}}$ & 45,00 \\
6 & $53,00^{\mathrm{bc}}$ & $41,67^{\mathrm{c}}$ & $40,30^{\mathrm{c}}$ & 42,40 \\
9 & $74,00^{\mathrm{b}}$ & $42,67^{\mathrm{c}}$ & $40,67^{\mathrm{c}}$ & 70,30 \\
12 & $124,30^{\mathrm{a}}$ & $44,67^{\mathrm{c}}$ & $42,00^{\mathrm{c}}$ & 78,89 \\
15 & $150,30^{\mathrm{a}}$ & $44,61^{\mathrm{c}}$ & $41,67^{\mathrm{c}}$ & 75,10 \\
18 & $139,60^{\mathrm{a}}$ & $44,00^{\mathrm{c}}$ & $41,67^{\mathrm{c}}$ & 70,70 \\
\hline Rata-rata & $128,30^{\mathrm{a}}$ & $43,00^{\mathrm{c}}$ & $41,00^{\mathrm{c}}$ & \\
\hline
\end{tabular}

a,b,c Superskrip yang berbeda menunjukkan perbedaan yang nyata.

berbeda dapat dilihat pada Tabel 1. Pertambahan jumlah koloni bakteri tampak menonjol pada daging yang telah 9 jam disimpan pada suhu kamar, sedangkan pada penyimpanan di refrigerator dan freezer, spora bakteri tidak aktif. Hal ini ditunjukkan oleh kenyataan bahwa koloni bakteri pada medium tidak mengalami perubahan yang nyata dengan betambahnya waktu penyimpanan.

Hasil anova menunjukkan bahwa terdapat beda nyata di antara perlakuan suhu dan lama penyimpanan. Hal ini berarti bahwa pada suhu yang berbeda pengaruh lama penyimpanan juga berbeda. Pada suhu kamar jumlah bakteri setelah disimpan 9 jam meningkat sangat pesat, tetapi perlakuan lain tidak. Penghitungan dengan DMRT menunjukkan bahwa jumlah bakteri pada suhu kamar selama 9; 12; 15 dan18 jam berbeda nyata dengan jumlah bakteri pada suhu dan lama penyimpanan yang berbeda.

Jumlah koloni bakteri pada penyimpanan di dalam refrigerator dan freezer tidak menunjukkan perbedaan yang nyata, jadi tampak bahwa bakteri yang hidup pada kedua tempat belum tumbuh sampai dengan 18 jam penyimpanan. Pada suhu kamar, mulai tampak meningkat pada penyimpanan 6 jam dan dan pada selang waktu 6 jam sampai 9 jam perupakan pertumbuhan paling cepat. Pengaruh suhu terutama pada aktivitas enzim yang dihasilkan oleh bakteri dalam mengkatalisis perubahan biokimia yang terjadi di dalam maupun di luar sel. Pada suhu rendah, pertumbuhan bakteri terhambat, meskipun demikian sampai batas tertentu bakteri tidak mengalami kematian, bakteri demikian disebut bakteri psikrofilik (Suriawiria, 1980). Bakteri ini ada pada daging yang disimpan pada refrigerator. Bakteri yang masih mampu tumbuh dapat dihambat bila disimpan di dalam freezer yang suhunya 0-10 C (Forrest et al, 1975). Suhu di bawah 50 C akan menghambat pertumbuhan bakteri pembusuk, bahkan dapat mencegah semua aktivitas bakteri patogen (Soeparno, 1994). Kematian bakteri pada suhu rendah disebabkan oleh terjadinya perubahan keadaan koloidal protoplasma yang tidak reversibel (Pearson dan Dutson,1986).

\section{Populasi Jamur Pada Daging}

Penyimpanan daging pada suhu yang berbeda menyebabkan jumlah spora yang bertahan pada daging berbeda pula. Hal ini tampak pada jumlah koloni yang terhitung pada kultur jamur di media buatan dari suspensi daging yang telah disimpan pada suhu dan lama penyimpanan yang berbeda (Tabel 2). 
Tabel 2. Jumlah jamur pada daging dengan suhu dan lama penyimpanan yang berbeda $\left(10^{4} / \mathrm{gram}\right)$

\begin{tabular}{ccccc}
\hline \hline Lama (jam) & \multicolumn{3}{c}{ Suhu Penyimpanan } & Rata-rata \\
\cline { 2 - 4 } penyimpanan & Kamar & Refrigerator & Freezer & 17,69 \\
0 & $18^{\mathrm{i}}$ & $18,67^{\mathrm{i}}$ & $17^{\mathrm{i}}$ & 26,40 \\
3 & $36^{\mathrm{i}}$ & $26^{\mathrm{i}}$ & $17,33^{\mathrm{i}}$ & 43,67 \\
6 & $73^{\mathrm{gf}}$ & $37^{\mathrm{i}}$ & $21^{\mathrm{i}}$ & 77,89 \\
9 & $144,33^{\mathrm{d}}$ & $61,67^{\mathrm{gh}}$ & $27,67^{\mathrm{i}}$ & 104,89 \\
12 & $191,33^{\mathrm{C}}$ & $93,67^{\mathrm{ef}}$ & $29,67^{\mathrm{i}}$ & 127 \\
15 & $251,67^{\mathrm{b}}$ & $97,67^{\mathrm{ef}}$ & $31,67^{\mathrm{i}}$ & 140,33 \\
\hline Rata-rata & $268,67^{\mathrm{a}}$ & $102,33^{\mathrm{e}}$ & $50^{\mathrm{hg}}$ & \\
\hline
\end{tabular}

Keterangan : Superskrip yang berbeda menunjukkan perbedaan yang nyata.

Dari hasil anova didapatkan bahwa ada perbedaan yang nyata antara kombinasi perlakuan suhu dan waktu penyimpanan, dan terdapat interaksi. Jadi dalam hal ini pertumbuhan jamur pada lama penyimpanan tertentu pengaruhnya berbeda jika daging disimpan pada suhu yang berbeda. Menurut Rice (1971), pertumbuhan yang optimum terjadi pada suhu kamar $\left(20-35^{0} \mathrm{C}\right)$. Pada Refrigerator, yaitu suhu $\left(5-7^{0} \mathrm{C}\right)$, jamur masih dapat tumbuh, meskipun tidak secepat pada suhu kamar. Tampaknya laju pertumbuhan paling tinggi terjadi pada penyimpanan 9 jam, hal ini menunjukkan bahwa sel muda yang tumbuh makin banyak karena adaptasi telah tercapai. Kenyataan bahwa daging belum menunjukkan gejala pembusukan pada jam ke 9 ini, berarti nutrisi belum banyak yang digunakan jamur dan zat toksik belum terbentuk. Jamur psikrofil tumbuh optimum pada suhu $15^{0}$ C. Jamur inilah yang tumbuh pada daging yang disimpan dalam refrigerator. Sementara itu daging yang disimpan dalam freezer tetap dapat ditumbuhi jamur karena suhunya berada pada $0^{\circ} \mathrm{C}$, tetapi kondisinya tidak aktif sehingga keberadaannya tidak akan mengubah komposisi kimia daging. Dalam penelitian ini sampai dengan penyimpanan 18 jam dalam freezer, secara visual kondisi daging masih tetap segar, walaupun sebenarnnya menurut Sudarmadji dkk (1989), khamir dari jenis asporogenus masih mampu tumbuh pada suhu $0^{0}$ sd $-1,6^{0}$ C. Khamir ini pada daging sapi biasanya bersifat lipolitik, sehingga aktivitasnya merusak daging.

\section{Permulaan Pembusukan pada Daging}

Pengujian awal dengan Eber, menunjukkan bahwa daging yang dibiarkan pada suhu kamar sudah mulai melepaskan gas hasil pembusukannya pada jam ke 9. Hal ini ditunjukkan adanya hasil reaksi uap $\mathrm{HCl}$ dari reagen Eber dengan $\mathrm{NH}_{3}$ dari daging. Reaksi ini menimbulkan embun putih membentuk cincin pada dinding tabung reaksi. Sampai pada jam ke 18 penyimpanan di refrigerator dan freezer, daging belum mengalami pembusukan (tabel 3), hal ini sesuai dengan keaktifan prtumbuhan bakteri dan jamur.

Enzim yang dilepaskan ke media, oleh bakteri danm jamur digunakan untuk mengubah senyawa pada media agar menjadi senyawa sederhana yang terlarut, sehingga dapat berdifusi ke dalam sel mikroorganisme tersebut dan digunakan untuk metabolisme. Enzim pembusuk pada daging adalah eksoenzim yang proteolitik maupun lipolitik, yang secara umum akan bekerja optimal pada suhu kamar. Secara umum enzim akan bekerja optimal pada suhu 10-60 ${ }^{\circ} \mathrm{C}$ (Pelzar dan Chan, 1986). Pada penelitian ini pembusukan terjadi pada 
Tabel 3. Hasil pengujian dengan reagen Eber pada daging dengan suhu dan lama penyimpanan yang berbeda kebusukan daging menggunakan Reagen

\begin{tabular}{cccc}
\hline \hline Lama (jam) & \multicolumn{3}{c}{ Suhu Penyimpanan } \\
\cline { 2 - 5 } penyimpanan & Kamar & Refrigerator & Freezer \\
\hline 0 & - & - & - \\
3 & - & - & - \\
6 & - & - & - \\
9 & + & - & - \\
12 & + & - & - \\
15 & + & - & - \\
18 & + & &
\end{tabular}

Keterangan : - tidak terbentuk embun putih $\mathrm{NH}_{4} \mathrm{Cl}$

+ terbentuk embun putih $\mathrm{NH}_{4} \mathrm{Cl}$

daging yang disimpan pada suhu kamar, karena mikroorganisme pembusuk dapat bermetabolisme tanpa hambatan. Enzim dapat bekerja optimal pada suhu kamar, karena suhu kamar rata-rata $28^{0}$ C, sedangkan di refrigerator hanya $7^{0} \mathrm{C}$ dan di freezer $0^{\circ} \mathrm{C}$.

\section{KESIMPULAN}

Dari penelitian ini dapat disimpulkan bahwa :

1. Suhu sangat menentukan pertumbuhan mikroorganisme pada daging.

2. Pada suhu rendah perkembangan populasi bakteri dan jamur dapat dihambat.

3. Pada refrigerator dan freezer, sampai dengan penyimpanan 18 jam populasi bakteri belum berkembang

4. Walaupun sangat lambat populasi jamur pada daging yang disimpan di dalam freezer ternyata tetap dapat bertambah.

5. Pembusukan terjadi pada jam ke 9 pada daging yang disimpan pada suhu kamar.

6. Dalam refrigerator maupun freezer kualitas mikrobiologi daging masih tetap bertahan sampai dengan 18 jam penyimpanan.

\section{DAFTAR PUSTAKA}

Bernholdt, H.F.,1975., Enzim in Food Processing: Meat and Other Proteinaceus Food, $2^{\text {nd }}$ ed. G. Readed Academy Press, New york.

Fardias, S., 1989., Mikrobiologi Pangan, PAU Pangan dan Gizi. Institut Pertanian Bogor, Bogor.

Forrest, 1975., Principle of Meat Science, W.H. Freman and Co. San Fransisco.

Naruki S, dan Sri Kanoni., 1992, Kimia dan teknologi Pengolahan Hasil Hewan. Kimia dan Pengolahan Daging . PAU, Universitas Gadjah Mada, Yogyakarta.

Pearson, A.M. and T.R. Dutson., 1986, Meat and Poultry Microbiology, Advances in meat Research, Michigan, New York.

Pelezar Michael J. and E.C.S. Chan, 1976. Element of Microbiology, Mc.Graw-Hill Book Company Inc., New York, Toronto, London.

Rahayu, K, 1989. Mikrobiologi Pangan, PAU Pangan dan Gizi, Universitas Gadjah Mada, Yogyakarta.

Rice, E., 1971., The Science vof Meat and Meat Product: The Nutritional Content and Value of Meat and Meat Products, $2^{\text {nd }}$ ed., J.F. Price and B.S. Scheigert, W.H. Freeman and Co., San Fransisco. 
Saile., 1961, Fundamental Principles of Bacteriology, $5^{\text {th }}$ ed. Mc. Graw-Hill Book Company Inc., New York, Toronto London.

Soeparno, 1994, Ilmu dan Teknologi Daging, Fakultas Peternakan Universitas Gadjah Mada, Yogyakarta.
Soedarmadji., Rahayu, dan Kapti., 1989. Mikrobiologi Pangan, PAU Pangan dan Gizi, Universitas Gadjah Mada, Yogyakarta.

Suriawiria, Unus., 1983, Mikrobiologi Umum, Institut Teknologi Bandung, Bandung.

Tranggono., 1990, Kimia dan Nutrisi Pangan, PAU Pangan dan Gizi, Universitas Gadjah Mada, Yogyakarta. 